\title{
ПРИНЦИПЫ СИНЕРГЕТИКИ ПРИМЕНИТЕЛЬНО К ОПИСАНИЮ КОНЦЕПТОВ
}

В данной статье рассматривается прочесс применения приничиов синергетической науки к исследованиям внутри когнитивной лингвистики. В ней представлен ход изучения кониепта счастье в рамках жанра антиутопии при применении принципов синергетики, а также основные результаты данного исследования.

Ключевые

лингвосинергетика, когнитивная антиутопия

This article presents the process of applying synergetic methods to the researching within a field of cognitive linguistics. This paper also demonstrates the flow of the researching of a concept of «cyacmbe» («happiness») within a dystopian genre using the synergetic methods, as well as the key results of the research.

Keywords: synergetics, linguosynergetics, cognitive synergetics, cognitive linguistics, concept of happiness, dystopia

Г. Хакен определяет синергетику как науку междисциплинарного характера, исследующую самоорганизацию элементов и структур в открытых системах [Хакен 1980: 20]. В настоящее время синергетическая мысль находит применение в самых разных областях науки, как и в естественных, так и в гуманитарных. Универсальность принципов и законов синергетики позволяет ей примыкать практически к любой 
научной мысли, обогащая ее новыми и свежими подходами к соответствующим объектам исследования.

Так, синергетические принципы находят огромный отклик и в рамках языкознания, так как язык является сложной, динамичной и самоорганизующийся системой [Гураль 2007: 7], перенося принципы самоорганизации системы как на язык в целом, так и на многие другие его аспекты.

Цель данной работы - продемонстрировать применимость идей синергетической парадигмы к исследованию концептов базовых единиц исследования когнитивной лингвистики.

По определению Поповы З.Д. и Стернина И.А. концепт это базовая ментальная единица мышления, содержащая комплексную информацию о предмете или явлении, образующаяся в результате познавательной деятельности индивидуума. Концепт не однороден, и наполнен множеством понятийных элементов - сем, совокупность которых и делает концепт таким, каким он предстает в нашем сознании [Попова, Стернин 2007: 25].

Таким образом, мы будем рассматривать концепт как целостную открытую систему, отличающийся динамичностью, и обладающей способностью к самоорганизации, а элементами этой системы мы будем считать его понятийные компоненты семы.

Согласно основному принципу синергетики, любая открытая система проходит через семь стадий развития, которые и колеруют с семью основными принципами синергетики - две стадии порядка (гомеостаз и иерархичность), и пять стадий становления (нелинейность, незамкнутость, неустойчивость, эмерджентность и наблюдаемость) [Буданов 2008: 22-28].

- Гомеостаз - система характеризуется стабильностью и наличием цели, к которой она стремится - аттрактором;

- Иерархичность - система характеризуется наличием упорядоченных элементов, строго подчиняющихся друг другу;

- Нелинейность - система характеризуется инвариантностью - еe развитие невозможно точно спрогнозировать. В момент неравновесности система будет стремиться к точке биффуркации - моменту, когда она сможет сменить аттрактор на новый, или вернуться к старому; 
- Незамкнутость - система характеризуется невозможностью пренебрежения её взаимодействием со своим окружением;

- Неустойчивость - система подвергается флуктуациям благодаря чему происходит повышение чувствительности к внешнему миру, и, как следствие, у системы появляется перспектива возникновения более совершенных форм организации.

- Эмерджентность - внутри системы зарождается новое качество, в результате чего она проходит точку бифуркации и обзаводится новой структурой

- Наблюдаемость - система характеризуется относительностью процесса приобретения знаний о системе [Буданов 2008:22-38].

Таким образом, можно утверждать, что и система концепта на протяжении своего существования будет подвержена данным стадиям самоорганизации. Действительно, в той или иной степени один и тот же концепт обязательно «переживет» процесс самоорганизации, так как его наполнение никогда не будет однородным на протяжении его существования. Например, то, что современный человек может понимать под такими понятиями как «письмо» (рукотворное - электронное) или «сообщение» (устное- SMS) будет значительно отличаться от того, что всплывет в сознании человека, жившего 100 лет назад.

Однако, говоря о более сложных, нематериальных понятиях, таких как «любовь», «свобода», «дружба», «душа» и т.п., можно ли с той же смелостью утверждать, что они претерпевают какие-либо значительные изменения? Чтобы дать ответ на этот вопрос, данная работа продемонстрирует когнитивно-синергическое исследование концепта «счастье» в дискурсе антиутопии. Данный жанр изобилует искаженными взглядами на духовные понятия, заново открывая читателю глаза на их истинную сущность, а также наглядно демонстрирует не только как именно такой сложный концепт как «счастье» может претерпеть значительные изменения, но также возможность быстрой динамики такого изменения.

И так, для начала нужно выделить состояние гомеостаза системы концепта «счастье» в дискурсе антиутопии. Таковым 
мы будем считать наличие в нем тех компонентов, которые были привиты обществу антиутопическим государством: «счастье»это в первую очередь стабильность, благополучие и удовлетворение базовых потребностей. Даже иерархичность во многих произведениях жанра может соответствовать данному порядку - от стабильности общества зависит его благополучие, а от благополучия зависит удовлетворение потребностей индивидуума. Данная политика активно пропагандируется тоталитарными властями, чтобы искоренить из концепта «счастье» все неугодные ему компоненты (свобода, любовь, познание и др.), и герой ей поддается:

В самом деле: есть ли где счастье мудрее, безоблачнее, чем в этом чудесном мире. $<\ldots>$ (E. Замятин «Мыл»)

- <..> планеты, достигшие, как наша земля, вериины абсолютного, стопроцентного счастья... (Е. Замятин «Мыл»)

- Счастье произойдет от материализма, товариш Вощуев, а не от смысла. (А. Платонов «Котлован»)

Однако, в какой-то момент, система ценностей протагониста претерпевает изменения. Он вдруг начинает осознавать «неправильность» восприятие концепта «счастье». Таким образом, система концепта в его сознании нелинейна и незамкнута - под воздействием внешних факторов, она стремится к новому аттрактору, так как старые (стабильность, благополучие, удовлетворение и m.n.), ее больше не устраивают.

- В надежде на райское счастье,

Не день, и не два, и не год,

Без веры в чужое участье

Гниет-проиветает народ. (А. Зиновьев «Зияющие высоты»»)

Как результат, система становится неустойчивой, так как герой начинает четко осознавать свое видение «счастья». Он видит, что оно кроется не только в благополучии, что настоящее человеческое «счастье» в первую очередь в свободе выбора, в близости с другими людми, в творчестве и др.. Внутри системы зарождается новый элемент (или даже несколько), демонстрируя ее эмерджентность, полностью меняя ее структуру, отбросив на 
второй план искаженные антиутопическим мировоззрением компоненты.

- And suddenly I felt the disappointment ebbing away and being replaced by a real happiness. We didn't do things like hug each other much at Hailsham. But I squeezed one of her hands in both mine when I thanked her. (Kazuo Ishiguro "Never Let Me Go")

Так мы видим, что система концепта «счастье» в рамках жанра антиутопии безусловно проходит все стадии самоорганизации системы. Это помогает не только подтвердить изменчивость данного концепта в рамках жанра, но и установить его новые элементы. Таким образом, принципы синергетики отлично ложатся на исследования в рамках когнитивной лингвистики, а такая отрасль как когнитивная лингвосинергетика обладает большим потенциалом в разработке новых методов при помощи синергетического аппарата.

\section{ЛИТЕРАТУРА}

1. Хакен Г. Синергетика. - М.: Мир, 1980. - 405 с.

2. Гураль С.К. Синергетика и лингвосинергетика // Вестник томского государственного университета. - 2007. - № 302. - С. 7-9.

3. Попова З.Д., Стернин И.А. Семантикокогнитивный анализ языка: монография. В.: Научное Издание, 2007. 250 с.

4. Буданов В. Г. Методология синергетики в постнеклассической науке и в образовании. - М.: Издательство ЛКИ, 2008. - 240 с.

(C) Старикова Д.Д., 2021 г. 